\title{
INTERPRETATION OF THE SUBJUNCTIVE IN MODERN GREEK AS A FOREIGN LANGUAGE: A CASE STUDY OF SERBIAN STUDENTS ${ }^{1}$
}

The paper explores the semantic aspect of modality and, in particular, perfectivity in the usage of Modern Greek subjunctive by Serbian students of Modern Greek Studies, at the University of Belgrade. The subjunctive mood is not always comprehensible; hence, learners of Greek as a second/foreign language make a concerted effort to become aware of it. According to Comrie (1967:16): "perfectivity indicates the view of a situation as a single whole, without distinction of the various separate phases". On the other hand, the imperfective is expressed by an ongoing or repeated action. Whether the subjunctive expresses the perfective or the imperfective is a question that a group of Serbian students were asked to figure out. More specifically, 78 native speakers of Serbian and L2 learners of Greek were tested on the comprehension of a number of subjunctives by means of a translation task. Based on error analysis, the results indicated that aspectual distinction is a matter of negative transfer from the mother tongue, but this is not always the case.

Key words: subjunctive mood, aspect, aspectuality, Greek as a foreign language

\footnotetext{
* $\quad$ vojkans@hotmail.com

** The paper was written within the project number 178002 Jezici i culture $u$ vremenu i prostoru [Languages and Cultures in Time and Space], financed by the Ministry of Education, Science and Technological Development of the Republic of Serbia.

1 Paper presented at the $6^{\text {th }}$ International congress of Applied Linguistics today: Language, Literature and Interdisciplinarity, Belgrade, Serbia, 12 October 2018.
} 
Vojkan B. Stojičić / Martha P. Lampropoulou / Anka M. Janković

\section{Objectives}

The subjunctive is usually considered to be a problematic area in Greek as an L2 or as a foreign language. This is confirmed by various studies concerning Greek and non-native speakers of different linguistic

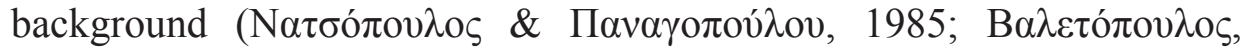

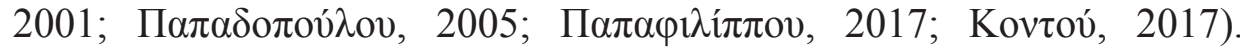
For instance, Anastasiadi- Symeonidi et al. (Av $\alpha \sigma \tau \alpha \sigma i \alpha ́ \delta \eta-\Sigma v \mu \varepsilon \omega v i ́ \delta \eta$, $\mathrm{B} \lambda \dot{\varepsilon} \tau \sigma \eta$ et al., 2008) underline the difficulty of L2 learners of Greek to choose the perfective or the imperfective when forming the subjunctive. In a previous research of Lampropoulou and Stojičić $(\Lambda \alpha \mu \pi \rho \operatorname{lov} \lambda \mathrm{ov}$ \& $\Sigma \tau$ ó $\tau \sigma \tau \tau \zeta, ~ 2018)$, Serbian students of Greek exhibited errors in oral and written tasks during exams; errors in the usage of the right form in specific communicative situations and linguistic context. This triggered our curiosity to study further this grammatical area and, for this reason, the examples used in our questionnaire were taken from students' essays, meaning they were based on instances of erroneous sentences which were recorded in Lampropoulou and Stojičić $(\Lambda \alpha \mu \pi \rho \circ \pi \circ v i \lambda o v \& \Sigma \tau$ \& 2018). Our intention is to attest how these instances of the subjunctive would be perceived by other students, native speakers of Serbian, and whether they would make similar mistakes employing the wrong form of the subjunctive (perfective or imperfective). On the whole, we aim at finding out how Serbian learners of Greek would conceptualize the notion of perfectivity in Greek.

\section{Introduction}

\subsection{Teaching Greek as a second/ foreign language and the notion of perfectivity}

In the various textbooks for learning Greek as a second/foreign language, the grammatical phenomena are graded intuitively according to their degree of difficulty and based on the stages of acquisition of Greek

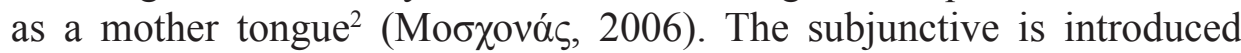

2 Among the textbooks which are used in the classroom are: Taksidi stin Ellada

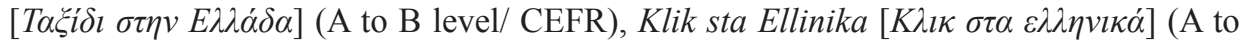

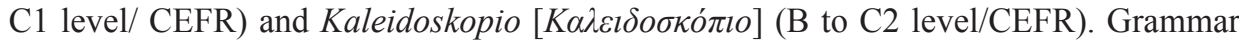

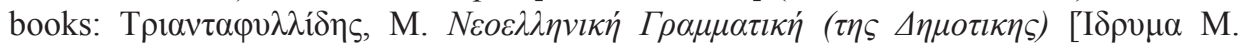


at the beginners' level since it is frequently incorporated in simple communicative tasks such as talking about personal preferences, habits and everyday routines.

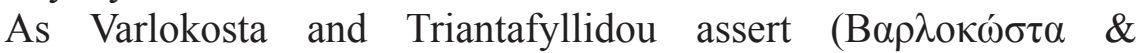

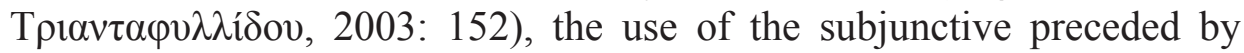
the particle $n a$ is quite productive at the beginner's level and it does not cause any difficulty in terms of conceptualization. For instance, beginners do form examples such as: $v \alpha \delta o v \lambda \varepsilon ́ \psi \omega$ - 'to work', $v \alpha \sigma \pi o v \delta \alpha \dot{\sigma} \sigma \omega$ - 'to study' etc. Or resort to small talk forming utterances such as example

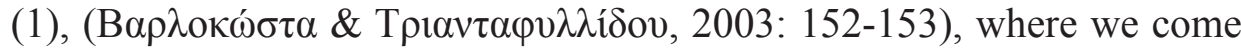
across the imperfective:

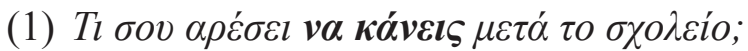

'What do you like doing after school?'

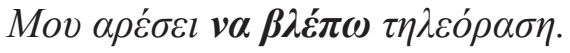

'I like watching TV.

The same applies for constructions with the impersonal can/could plus the subjunctive; a form which expresses potentiality (ibid.).

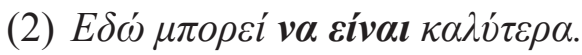

'It could be better here.'

However, learners encounter problems when they have to employ mediopassive voice (ibid.):

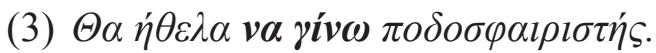

"I would like to become a footballer."

In terms of the subjunctive, the textbooks do not expand on the way aspect and perfectivity are theoretically approached in Modern Greek

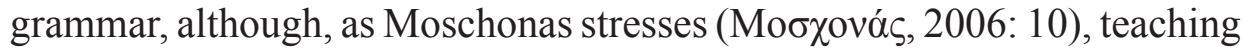
Greek as a second/foreign language follows similar practices to teaching Greek to native speakers at school. The latter is true especially when the lesson is adult oriented. Textbooks for adults do use metalanguage, since metalinguistic information regarding grammatical phenomena

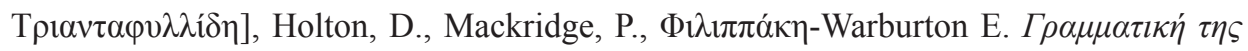

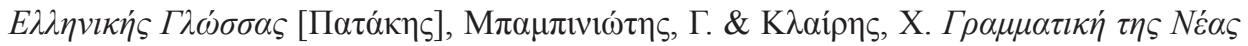

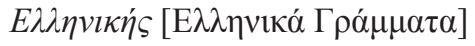


can be better processed and understood by them. However, in the case of the subjunctive due to its complex nature and subtle nuances, further clarification and exemplification is usually provided by the instructor. For instance, the notion of perfectivity is usually the subject matter of discussion when grammar is taught at advanced levels (B2 and C2).

More specifically, perfectivity is presented as the medium which indicates the view of a situation as a single whole, without distinction of the various separate phases (Comrie, 1967). On the other hand, the imperfective is expressed by an ongoing or repeated action. Moreover, the semantic features related to the perfective/imperfective distinction in Greek include [+/-bounded] and [+/-iterative] (Mozer ,1994).

\subsection{The subjunctive in Greek}

In Modern Greek, the mood involves the indicative, the subjunctive

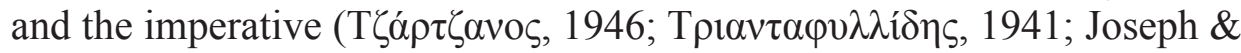

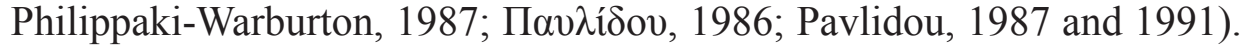
Joseph \& Philippaki-Warburton (1987: 180) state that:

The formal difference between indicative and subjunctive correlates with a fundamental semantic distinction between sentences which present an action or state as factual and thus locate it in time - present, past, or future - and sentences which express the attitude of the speaker (in main clauses) or of the higher subject (in subordinate clauses) to an event or state which is not presented as a fact (either of the present, past, or future), but which could become a fact.

The subjunctive is introduced by means of particles, that is, the particles na ('to') and as ('let's', 'let him/her', etc.) which precede a verb stem, either in the imperfective aspect or in the perfective and it can be employed both in dependent and in independent clauses with the corresponding co-occurrence restrictions on the set of subjunctive particles (Pavlidou, 1991: 13). As a rule $n a$-clauses stand for a possible state of affairs (Rouchota, 1994). More specifically, in the subjunctive mood the same verb has the following forms (Pavlidou, 1991: 13): 
$>$ as/na trexo (imperfective aspect)

(4) Mov $\alpha \rho \varepsilon ́ \sigma \varepsilon l v \alpha \tau \rho \varepsilon ́ \chi \omega$. "I like running."

$>$ as/na trekso (perfective aspect)

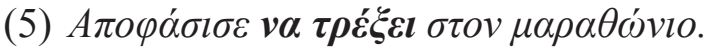
"He decided to run in the marathon."

The notions that characterize the subjunctive vary and depend on the speaker's attitude towards the content of the sentence s/he utters

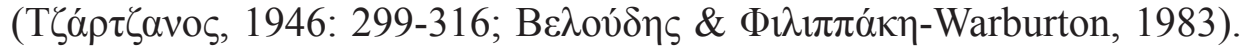
According to Smith (1991), aspect, or else, viewpoint aspect has to do with the way the speaker chooses to present a situation or an event. The personal point of view when narrating events is determining in using the perfective or the imperfective: the perfective, or else, the aoristic aspect, presents an action as a simple whole, or else a telic event, whereas the imperfective aspect describes a continuous or habitual (repetitive) action, independently of whether that action takes place in the past, the present, or the future. To put it differently, the perfect subjunctive is connected with an end point of the action, whereas the imperfect subjunctive is connected with duration. Similarly, Kitis and Tsangalidis (2005) relate the distinction between perfective and imperfective with the semantic features of the

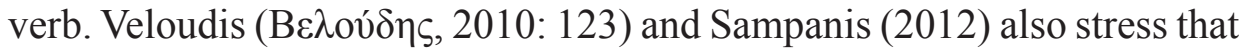
the subjunctive is semantically conditioned. For instance, the subjunctive can also be used in rhetorical questions which have a phatic function (example 6, Pavlidou, 1991: 22), or in indirect requests for permission to do something, as in example (7):

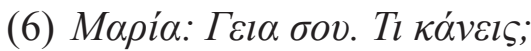

Maria: 'Hi. How are you?'

$\Delta \omega ́ \rho \alpha: T i v \boldsymbol{\alpha} \boldsymbol{\kappa} \alpha \dot{v} \boldsymbol{\omega}$; (imperfective)

Dora: 'How should I be?'

(7) $N \alpha \mu \imath \lambda \dot{\eta} \sigma \omega ;$ (perfective)

'Could I talk?'

Moreover, the subjunctive is used in non-interrogative independent clauses expressing a wish, a curse or exhortation: 
(8) $N \alpha \tau \rho \omega \varsigma \kappa \alpha \lambda \alpha \dot{!}$ (imperfective)

'You should eat well'!

The subjunctive involves other uses, yet, we will not expand in all cases since the scope of the present work is to examine students' performance by means of specific examples.

\subsection{The subjunctive in Serbian}

Unlike Modern Greek, Serbian does not have the category of the subjunctive mood, but its functions are realized by using the particle $d a+$ present tense. Traditional grammars of Serbian language do not mention the category of subjunctive (seе Стевановић, 1981; Станојчић \& Поповић, 2000; Пипер, Антонић et al., 2005). The reason for this may be the fact that in some languages subjunctivity may be expressed at a morphological level, while in some other languages it is expressed at a semantic level. For illustrating this claim, we should mention the category of verbal aspect, which is also one of the grammatical categories expressed in different ways in various languages. For instance, in Serbian language the subjunctive is a semantic category, while in Modern Greek it is a morphological one, which is not the case with the category of verbal aspect. Namely, while the category of verbal aspect in Serbian is grammaticalized, in Modern Greek it can be observed at a syntactic level.

It may cause confusion when comparing and contrasting these two languages, but the key to this comparison is not the subjunctive mood itself, but the notion and expression of the category of aspect. Therefore, in order to understand the main similarities and differences in the verbal systems of the two languages, it is important to emphasize that all verbs in the Serbian language have their own aspect (perfective/imperfective), while in Modern Greek, the verbs get their aspect in context. It does not mean that because of that specific nature of Serbian verbs the situation in the context is not complicated; sometimes both the perfective and the imperfective get various specific contextualized meanings (Пипер \& Клајн, 2017: 175).

As a rule, perfective verbs cannot be used in the present tense in independent clauses. An action that is happening at the moment of speech is expressed by the present tense and, therefore, it is expressed by imperfective forms: 
(9) Čitam knjigu. (imperfective)

(I) read PRESENT a book.

(10) Pročitam knjigu*. (perfective)

There are only two exceptions to this rule:

The perfective present tense may be used:

1. in dependent clauses and it refers to the future (relative present tense):

(11) Oni traže da pročitam knjigu.

'They ask me to read a book.'

2. in order to express habitual actions:

(12) Svaki dan dođe, pogleda robu, ali ništa ne kupi.

'Every day s/he comes, looks at the clothes, but does not buy anything.'

From the morphological point of view, the formation of verbal aspect in Serbian differs a lot compared to the Modern Greek language. More specifically, aspect in Serbian can be expressed by the following means:

i. suffixes (-a-, -ava-, -iva-)

ii. prefixes (pro-, pre-, o-, na-)

iii. stem change (e.g. reći-govoriti)

iv. accent change (pOgledati-poglEdati)

v. description (by using aspectual verbs) (Пипер \& Клајн, 2017: 177).

\subsection{The acquisition of aspect by $L 2$ learners}

Taking into account that different languages may follow a different morphological and syntactic realization of the subjunctive, the acquisition of aspect and the discrimination of the two forms of perfectivity are areas that appear to be challenging for L2 learners of Greek. The current study, as mentioned, examines how Serbian learners of Greek treat the subjunctive and whether they encounter difficulties in using the correct form.

In general, aspect is an area that can create confusion even at an intermediate or advanced level i.e. A2 or B1/B2 level (П $\alpha \pi \alpha \delta$ o $\pi$ ov́ $\lambda$ ov, 2005; В $\alpha \lambda \varepsilon \tau o ́ \pi о v \lambda \circ \varsigma, 2001)$. The question that arises is what exactly causes 
difficulty in applying the notions of the subjunctive and perfectivity. Based

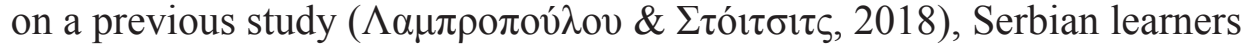
who have reached an A or B level seem to have acquired aspect but not fully mastered it; they are mostly based on context and less on syntax or grammar rules in their choice of the perfect or the imperfect subjunctive. Additionally, there is a tendency to use more the imperfective, probably due to the negative transfer from their mother tongue, yet, their overall performance is considerably good (ibid.). In their paper, Natsopoulos

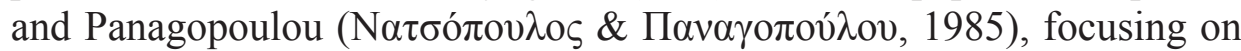
telicity, note that learners of Greek (of a European and Arabic linguistic background), who studied at School of Modern Greek, were able to use perfective and imperfective forms rather satisfactorily. However, in contrast to Lampropoulou and Stojičić ( $\Lambda \alpha \mu \pi \rho$ o noted that they tend to use more the perfective instead of the imperfective and overgeneralize the use of the perfective forms when a habitual event is communicated. These remarks also agree with other studies of non-native

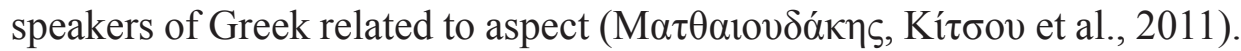
Along with aspect, other errors in verbal morphology are usually observed (i.e. tense, agreement).

Two factors could be responsible for this differentiation in the above studies. Firstly, it could be the different linguistic background of the participants, that is, their mother tongue. Anastasiadi-Symeonidi et al.

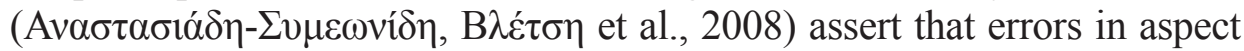

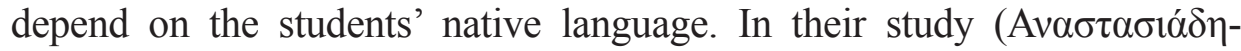
$\Sigma v \mu \varepsilon \omega v i \delta \eta$, A., B $\lambda \varepsilon \dot{\tau} \sigma \eta$, E. et al., 2008), they found that Russian learners of Greek made more mistakes in the use of the perfective, whereas the Albanian and the Swedish learners had difficulty in using the imperfective. Secondly, certain cases could be problematic due to their difficulty to be classified in terms of their grammatical function in the target language. For instance,

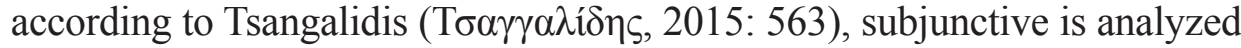
focusing solely on the verb and neglecting the elements that contribute to its formation i.e. the subjunctive particle $n a$. There is no unanimity as to whether this Modern Greek construction, which consists of the particle na ( $v a ́$ ) plus a verbal form constitutes a genuine mood or is merely a kind of predicate complement (ibid.). Thus, the way several constructions are classified might affect the way they are presented to adult L2 learners of Greek. 
INTERPRETATION OF THE SUBJUNCTIVE IN MODERN GREEK ...

\section{Experimental part}

\subsection{Design}

The empirical part involves the completion and analysis of a questionnaire and it was carried out during the spring semester of 2018. The questionnaire was administered in all four years. Students were presented with sentences in Serbian and their equivalent translation in Greek in two versions and they were asked to underline the correct equivalent translation. In fact, they were given the possibility to choose one equivalent translation in Greek either with a perfect subjunctive form or a second one where the verb expressed the imperfect subjunctive, one of them being ungrammatical. The questionnaires were handed back in approximately 15 minutes.

\subsection{Material}

More specifically, the questionnaire enumerated 20 sentences: 10 fillers and 10 items. All the sentences were in Serbian followed by their equivalent translation in Greek in two versions, one being ungrammatical, as mentioned previously. The questionnaire was completed by 78 students anonymously and at a voluntary basis, thus, the research is characterized by random sampling. It has to be noted here, that the sentences constitute cases that L2 learners of Greek find challenging and confusing in terms of deciding what is the appropriate subjunctive form, the perfective or the imperfective. In fact, the items were based on erroneous instances that L2 Serbians learners of Greek had produced at a written task

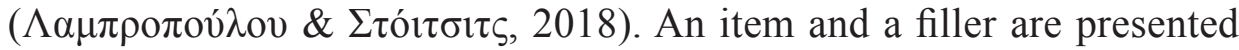
indicatively, below:

Item $5^{\text {th }}$ :

Сваки ученик лицеја треба да зна шта жели да студира (perfective/imperfective).

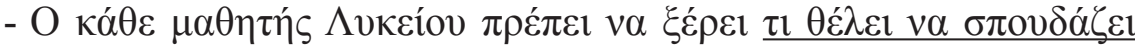
(imperfective).

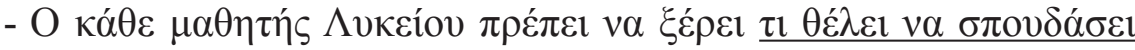
(perfective). 
'Every high school student should know what he would like to study ${ }^{3}$.'

The correct answer is perfective.

Filler:

Савремени човек трпи велики стрес.

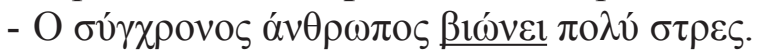

'The contemporary man experiences a lot of stress.'

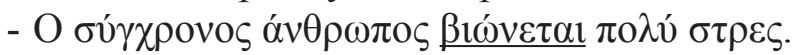

'The contemporary man is experienced a lot of stress."'

Table 1 shows the form of the subjunctive that the Serbian sentence bears and the form of the subjunctive required in the correct translated version of it.

\begin{tabular}{|c|c|c|}
\hline Items to be examined & Serbian sentence & Greek equivalent \\
\hline $1^{\text {st }}$ & Perfective & perfective \\
\hline $2^{\text {nd }}$ & Perfective & perfective \\
\hline $3^{\text {rd }}$ & Perfective & perfective \\
\hline $4^{\text {th }}$ & Imperfective & perfective \\
\hline $5^{\text {th }}$ & perfective/imperfective & perfective \\
\hline $6^{\text {th }}$ & Imperfective & imperfective \\
\hline $7^{\text {th }}$ & Imperfective & imperfective \\
\hline $8^{\text {th }}$ & Imperfective & perfective \\
\hline $9^{\text {th }}$ & Imperfective & imperfective \\
\hline $10^{\text {th }}$ & Imperfective & imperfective \\
\hline
\end{tabular}

Table 1

As seen, only the $4^{\text {th }}$, the $5^{\text {th }}$ and the $8^{\text {th }}$ item differ in terms of perfectivity.

3 The difference in meaning cannot be attributed in English, thus, there is a single equivalent example. 
INTERPRETATION OF THE SUBJUNCTIVE IN MODERN GREEK ...

\subsection{Participants}

The subjects were 78 undergraduate students of Modern Greek Studies, a rather satisfactory number of participants since the total number of students currently enrolled at the Department of Modern Greek Studies at the University of Belgrade reaches a number of 200 approximately. More specifically, the questionnaire was filled in by 15 students from the $1^{\text {st }}$ year, 26 students from $2^{\text {nd }}$ year, 13 students from $3^{\text {rd }}$ year and 24 students from $4^{\text {th }}$ year.

\subsection{Hypotheses}

There is a high possibility for students to choose the wrong form where the two languages differentiate in terms of the perfective/ imperfective distinction. And in addition to this, it is expected that students may resort more frequently to the impefective rather than the perfective, based on previous findings of Lampropoulou and Stojičić ( $\Lambda \alpha \mu \pi \rho \circ \pi \circ \lambda^{\prime}{ }_{0}$

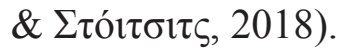

\subsection{Results}

Table 2 shows the percentages of correct responses, that is, how many students overall chose the right form of the subjunctive in Greek.

\begin{tabular}{|c|c|c|c|c|}
\hline & \multicolumn{4}{|c|}{ students correct responses } \\
\hline $\begin{array}{c}\text { sentences/ items } \\
\text { in Greek }\end{array}$ & $\begin{array}{c}\text { 1st year } \\
\text { (15 students) }\end{array}$ & $\begin{array}{c}\text { 2nd year } \\
\text { (26 students) }\end{array}$ & $\begin{array}{c}\text { 3rd year } \\
\text { (13 students) }\end{array}$ & $\begin{array}{c}\text { 4th year } \\
\text { (24 students) }\end{array}$ \\
\hline 1. perfective & $80 \%$ & $81 \%$ & $92 \%$ & $100 \%$ \\
\hline 2. perfective & $53 \%$ & $58 \%$ & $62 \%$ & $58 \%$ \\
\hline 3. perfective & $40 \%$ & $50 \%$ & $62 \%$ & $67 \%$ \\
\hline 4. perfective & $73 \%$ & $85 \%$ & $85 \%$ & $88 \%$ \\
\hline 5. perfective & $27 \%$ & $27 \%$ & $54 \%$ & $46 \%$ \\
\hline 6. imperfective & $73 \%$ & $78 \%$ & $77 \%$ & $83 \%$ \\
\hline 7. imperfective & $53 \%$ & $78 \%$ & $77 \%$ & $92 \%$ \\
\hline 8. perfective & $13 \%$ & $12 \%$ & $38 \%$ & $29 \%$ \\
\hline 9. imperfective & $53 \%$ & $58 \%$ & $62 \%$ & $46 \%$ \\
\hline 10. imperfective & $60 \%$ & $69 \%$ & $62 \%$ & $63 \%$ \\
\hline
\end{tabular}

Table 2 
We could say that students' performance was satisfactory. Mistakes were made in those items where the two languages differentiate ${ }^{4}$. And this can also be seen clearly in the following two tables ${ }^{5}$.

\begin{tabular}{|c|c|c|c|c|c|}
\hline & Item $\mathbf{1}$ & Item $\mathbf{2}$ & Item $\mathbf{3}$ & Item $\mathbf{4}$ & Item $\mathbf{5}$ \\
\hline Serbian & perfective & perfective & perfective & imperfective & imperf/perf \\
\hline Greek & perfective & perfective & perfective & perfective & perfective \\
\hline $\mathbf{1}^{\text {st }}$ year & perfective & perfective & imperfective & perfective & imperfective \\
\hline $\mathbf{2}^{\text {nd }}$ year & perfective & perfective & Perfective & perfective & imperfective \\
\hline $\mathbf{3}^{\text {rd }}$ year & perfective & perfective & Perfective & perfective & perfective \\
\hline $\mathbf{4}^{\text {th }}$ year & perfective & perfective & Perfective & perfective & imperfective \\
\hline
\end{tabular}

Table 3

\begin{tabular}{|c|c|c|c|c|c|}
\hline & Item 6 & Item 7 & Item 8 & Item 9 & Item 10 \\
\hline Serbian & imperfective & imperfective & imperfective & imperfective & imperfective \\
\hline Greek & imperfective & imperfective & perfective & imperfective & imperfective \\
\hline $\mathbf{1}^{\text {st }}$ year & imperfective & imperfective & imperfective & imperfective & imperfective \\
\hline $\mathbf{2}^{\text {nd }}$ year & imperfective & imperfective & imperfective & imperfective & imperfective \\
\hline $\mathbf{3}^{\text {rd }}$ year & imperfective & imperfective & imperfective & imperfective & imperfective \\
\hline $\mathbf{4}^{\text {th }}$ year & imperfective & imperfective & imperfective & perfective & imperfective \\
\hline
\end{tabular}

Table 4

\section{Discussion}

As mentioned earlier, the current study, examines how Serbian students of Greek treat the subjunctive and perfectivity in Greek and whether they encounter difficulties in using the correct form. Taking into account the results, it is interesting fact that the level of language mastery does not seem to play a role on the choice of the right form of the subjunctive. In terms of aspect in Greek, learners who have reached an $\mathrm{A}$ or $\mathrm{B}$ level $\left(1^{\text {st }}\right.$ and $2^{\text {nd }}$ year$)$ appear to be able to acknowledge the

$4 \quad$ See the items in grey.

5 The columns in grey indicate the items where Serbian students did not use the correct form of perfectivity. 
INTERPRETATION OF THE SUBJUNCTIVE IN MODERN GREEK ...

function of the subjunctive successfully. On the other hand, students of more advanced levels $-\mathrm{B} 2$ or $\mathrm{C} 1$ level ( $3^{\text {rd }}$ and $4^{\text {th }}$ year $)$ - also applied the correct form in the majority of items. For instance, in item 6, all groups indicated the imperfective:

Item $6^{\text {th }}$ :

После доста вежбе, научио је да чита. (imperfective)

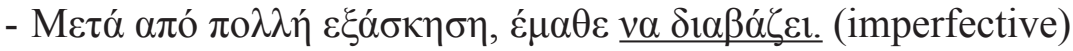

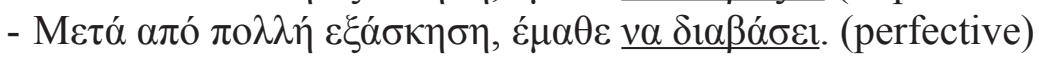

'After a lot of practice, he learned to read.'

The correct answer is the imperfective.

Even in the following item (2), where beginners of Greek as an foreign language usually form the wrong type of the mediopassive voice of the verb yivoual 'become', when they refer to their plans over their

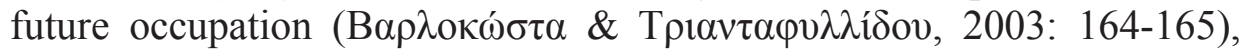
our participants indicated the correct equivalent in Greek, which is the perfective. Semantically, there is no difference in the two languages, the focus in Greek and in Serbian is on the endpoint, that of "achieving in becoming a doctor", expressing telicity, and not on the state, that of "being a doctor". The participants of the current study did not encounter any difficulty with this item:

Item $2^{\text {nd: }}$

Потребно је много учења да бих постао доктор. (perfective)

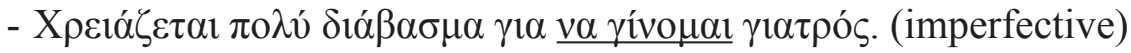

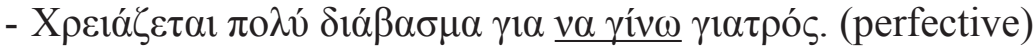

'It takes a lot of studying to become a doctor.'

The correct answer is the perfective.

\subsection{Problematic cases due to differences in the two languages}

As seen in the previous section, the discrimination of aspect in terms of the subjunctive mood is not quite challenging for Serbian students of Greek. The few points where students of all levels encountered difficulties are the points where the two languages diverge semantically. Those instances are explicitly presented below. 
In item (3), students' choice, that is, the perfective complies with the Greek equivalent. Only students from the $1^{\text {st }}$ year pinpointed the imperfective probably based on the assumption that getting sick and not being able to protect ourselves implies a periodic event. However, students from the second, the third and the fourth year interpreted the sentence with the perfect subjunctive attributing an epistemic modality to it: "cannot protect".

Item $3^{\text {rd: }}$

Шта се дешава када смо толико болесни да не можемо да заштитимо себе? (perfective)

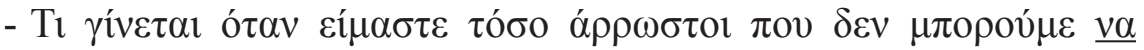

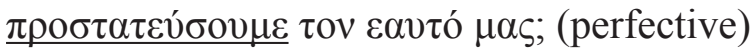

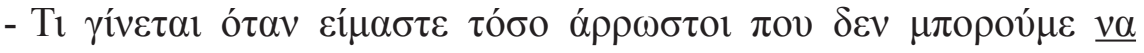

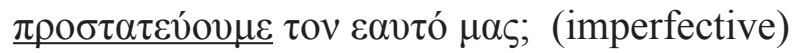

'What happens when we are so sick that we cannot protect ourselves?'

The correct answer is the perfective.

In item (5), Serbian students' responses diverge from the equivalent sentence in Greek, most probably being influenced by their mother tongue. All groups indicated the imperfective. In Serbian, both the perfective and the imperfective are acceptable in this sentence. In fact, the speaker in Serbian by means of the imperfective highlights the process of studying, or else, the period of studying. In contrast, in Greek, the verb $\sigma \pi o v \delta \alpha \dot{\zeta} \zeta \omega-$ 'to study' in this context requires the perfective displaying the result and the intention, and not the process. Semantically the use of the verb $\theta \dot{\varepsilon} \lambda \omega-$ 'want' (would like in English) along with the perfective $v \alpha \sigma \pi o v \delta \alpha$ o $\sigma \omega$ - 'to study' depict the choice of a discipline for future studies. In Greek, it is the will or the ability to study that is manifested.

Item $5^{\text {th: }}$

Сваки ученик лицеја треба да зна шта жели да студира. (perfective/imperfective)

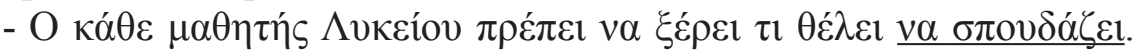
(imperfective)

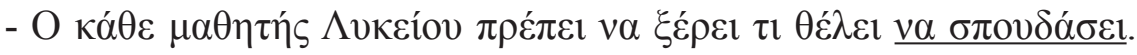
(perfective) 
INTERPRETATION OF THE SUBJUNCTIVE IN MODERN GREEK ...

'Every high school student, should know what s/he would like to study'

The correct answer is the perfective.

In item $8^{\text {th }}$, the majority of students pinpointed the imperfective, probably due to negative transfer from the mother tongue because in Serbian the duration and the repetition of an activity, especially when talking about sports or doing sports play a primary role. On the contrary, in Greek, the interest lies in the intention, or else, the will to get involved with sports, or else, the intention to achieve this will. For this reason, in Greek the correct equivalent is the perfective. This item constitutes a characteristic example of a semantic difference in the two languages.

Item $8^{\text {th: }}$

После лицеја бих волео да се бавим спортом. (imperfective)

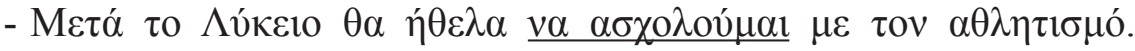
(imperfective)

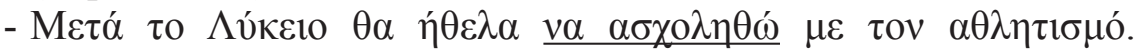
(perfective)

'After high school, I would like to get involved with sports.'

The correct answer is the perfective.

Finally, for item (9), the majority of students provided the correct answer: the imperfect subjunctive, which is the correct interpretation in Greek. However, fourth years students distinguished the perfect subjunctive version emphasizing habituality. This last case could be indicative of overgeneralization; the subjects did not even pay attention to

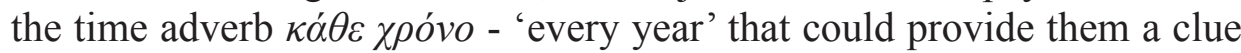
of the type of the subjunctive they could employ ${ }^{6}$. In spite of this group of participants (64\%), the rest of them (46\%) acknowledged the implication of a repetitive activity, that of attending various linguistic seminars (see Table 2).

6 The presence of adverbs of time is not always helpful in the formation of the

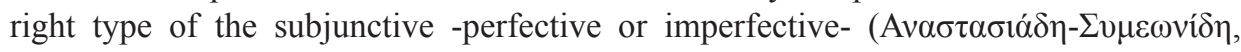

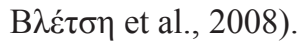


Item $9^{\text {th }}$ :

Сваке године имамо прилику да идемо на разне семинаре о језику. (imperfective)

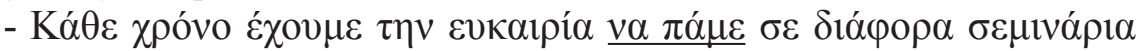
$\gamma 1 \alpha \tau \eta \gamma \lambda \omega ́ \sigma \sigma \alpha$. (perfective)

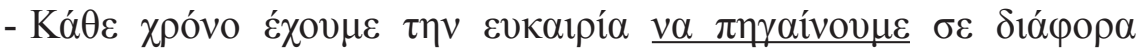
$\sigma \varepsilon \mu 1 v \alpha ́ \rho 1 \alpha \gamma 1 \alpha \tau \eta \gamma \lambda \omega ́ \sigma \sigma \alpha$. (imperfective)

'Every year, we have the chance to attend various seminars about language'.

The correct answer is the imperfective.

In those limited erroneous cases, there is a tendency to use the imperfective, probably due to the transfer from their mother tongue, something that was also observed in Lampropoulou and Stojičić

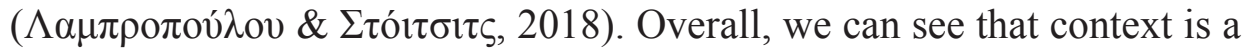
significant factor that affects the perfective/imperfective distinction.

\section{Concluding remarks and suggestions for future research}

The present research was an attempt to examine how Serbian students of Greek understand the notion of the subjunctive in terms of the perfective/ imperfective distinction. Independently of their level, the participants performed satisfactorily, showing that it is not the different formation of the subjunctive in the two languages that affects their performance, or the fact that in Serbian some verbs are characterized by two aspects, both the perfective and the imperfective. It would be worthy to keep in mind that even in Greek, there are verbs that express both the perfective and imperfective. Concluding, the subjects' wrong choices are related to the way they interpret the speaker's attitude in specific circumstances.

More specifically, the findings revealed that confusion can be created when students have to choose between focusing on the execution of the act or the result and the process of it. This leads us to the importance of the context and the speaker's intention since it determines the choice of the right form of perfectivity.

In order to enhance students' understanding, an effort is made, especially at the third and the fourth year of studying Greek, to exemplify 
the notions of mood, the subjunctive and perfectivity, as well as to explain the role of modality in Greek. In cases where the two languages divert, a juxtaposition is made between the grammatical system in Serbian and

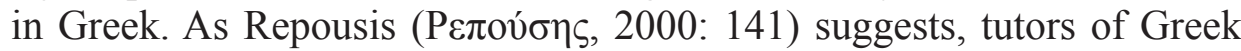
as a foreign language should be aware of the differences and similarities between L1 and L2 in order to help learners to develop the ease to apply the correct form. Therefore, we believe that by exemplifying the semantic differences in terms of the function of the subjunctive in the two languages, adult learners would have a better understanding of grammar. It should be added here, that metalanguage is not overused in the teaching process.

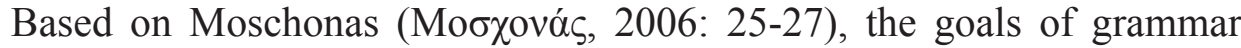
of a foreign language are the conquest of the linguistic system and its use. Taking this into account, the provision of a meta-lingual analysis is appropriate for the moment when the widespread use of a grammatical phenomenon has been achieved. This means that the learner will have reached that consciousness, which involves automatic and unconscious use of the phenomenon (ibid.). In order to enrich our knowledge of the way students cognitively internalize the function of the subjunctive, further research on the semasiological aspect of the subjunctive mood is required.

\section{REFERENCES}

Comrie, B. (1967). Aspect. Cambridge University Press, Cambridge.

Joseph, B., Philippaki-Warburton, I. (1987). Modern Greek. London and New York: Croom Helm.

Kitis, E., Tsangalidis, A. (2005). Expressivity as an option of tense-aspectaspect-mood in language: The case of Modern Greek imperfective past. In S. Marmaridou, K. Nikiforidou \& E. Antonopoulou (eds.), Reviewing Linguistic Thought: Perspectives into the 21st Century (Trends in Linguistics Studies and Monographs, 161) (pp. 143-162), Berlin and NewYork: Mouton de Gruyter.

Mozer, A. (1994). Đd'éüi ęáé Áđür̆léén ôd'ơ N̦Țéâôd’n̆. Athens: Parousia.

Pavlidou, T. (1987). On the interplay between interrogativity and the subjunctive: The case of Modern Greek. In W. Bahner, J. Schildt \& D. Viehweger (eds.), Proceedings of the XIVth International Congress of Linguistics, Berlin: Akademie Verlag. 
Vojkan B. Stojičić / Martha P. Lampropoulou / Anka M. Janković

Pavlidou, T. (1991). Cooperation and the choice of linguistic means: Some evidence from the use of the subjunctive in Modern Greek. Journal of Pragmatics, 15/1, 11-42.

Rouchota, V. (1994). The Subjunctive in Modern Greek: Dividing the Labor Between Semantics and Pragmatics. Journal of Modern Greek Studies 12 (2), 185-201.

Sampanis, K. (2012). A semantic features analysis for the Subjunctive mood. Wiener Linguistische Gazette 76A, 3-25.

Smith, C. (1991). The Parameter of Aspect. Dordrecht, Boston and London: Kluwer Academic Publishers.

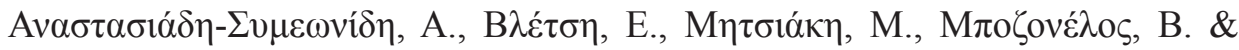

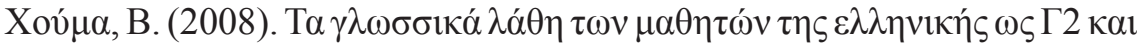

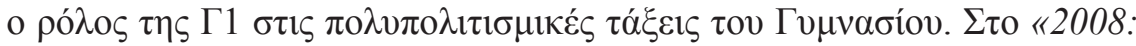

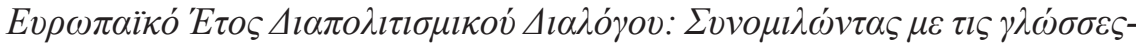

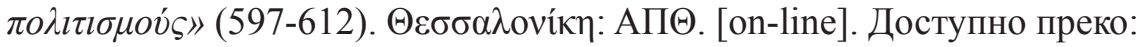
www.frl.auth.gr/sites/congres/Interventions/.../anastassiadis-symeonidis. pdf [24.1.2020]

В $\alpha \lambda \varepsilon \tau$ đó

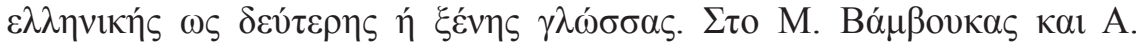

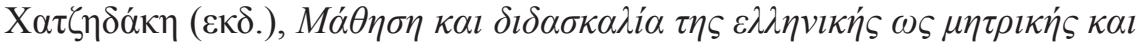
$\omega \varsigma \delta \varepsilon v \dot{\tau \varepsilon \rho \eta \varsigma ~ \gamma \lambda \omega ́ \sigma \sigma \alpha \varsigma ~(59-69) . ~ A \theta \eta ́ v \alpha: ~ A \tau \rho \alpha \pi o ́ s . ~}$

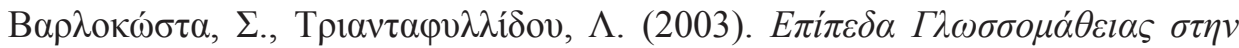

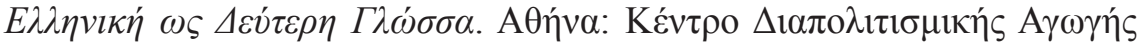

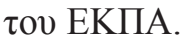

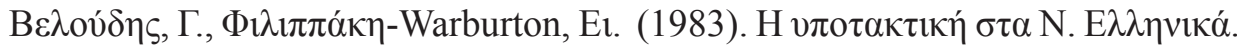

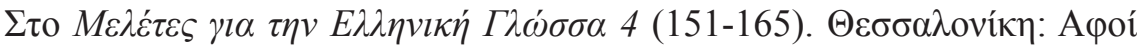

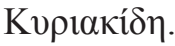

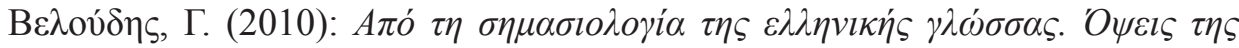

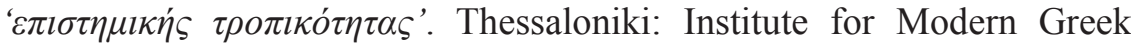
Studies.

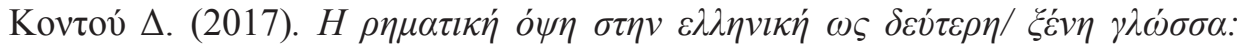

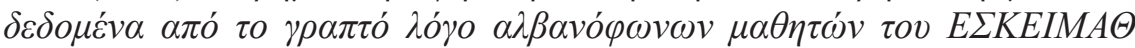

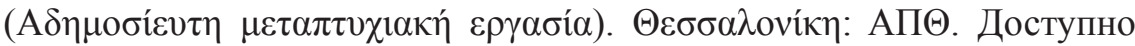
преко: http://ikee.lib.auth.gr/record/301336/files/GRI-2018-23133.pdf [24.1.2020]

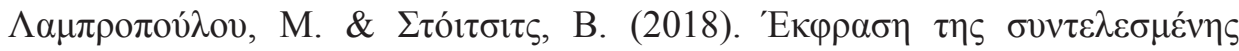

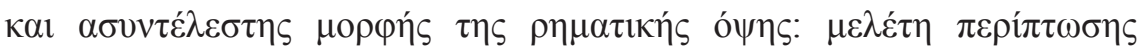

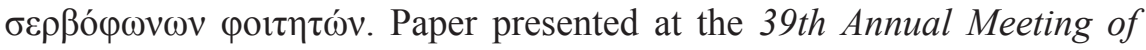


INTERPRETATION OF THE SUBJUNCTIVE IN MODERN GREEK ...

the Department of Linguistics, Aristotle University of Thessaloniki, 18-20 April 2018, Thessaloniki, Greece.

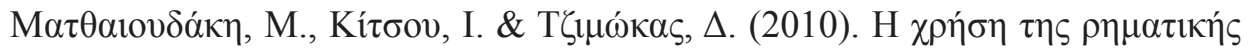

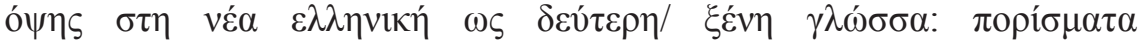

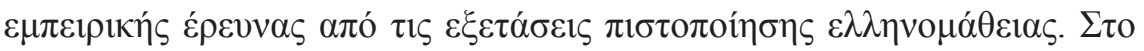

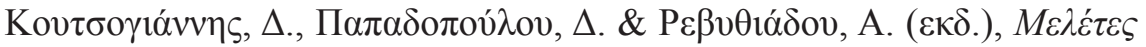

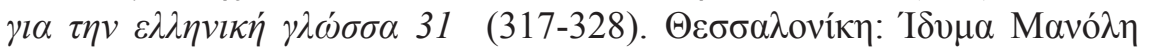

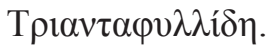

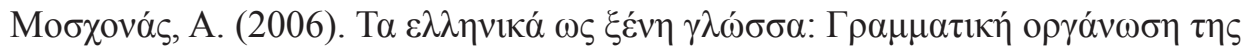

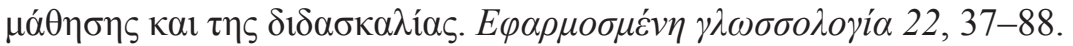

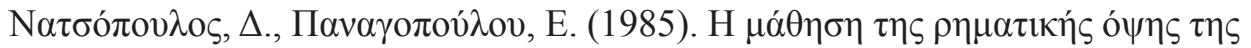

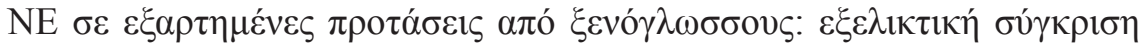

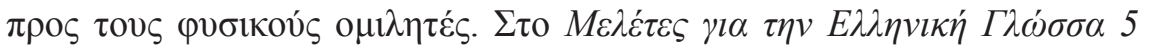

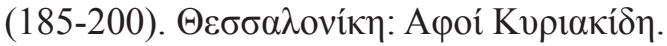

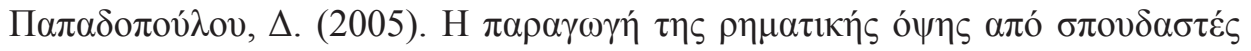

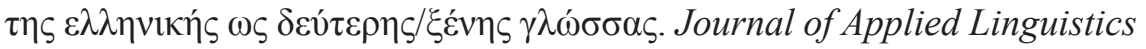
$21,39-54$.

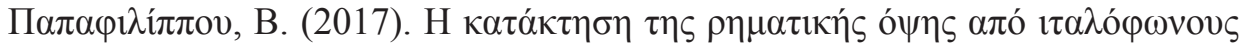

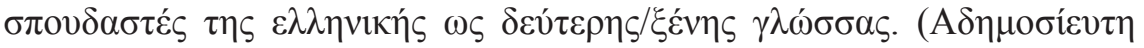

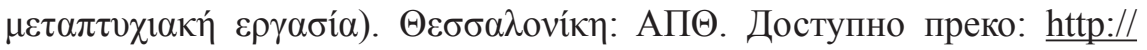
ikee.lib.auth.gr/record/292933? ln=el [24.1.2020].

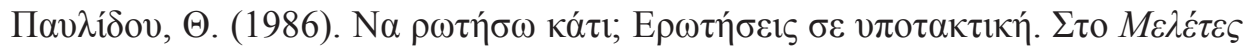

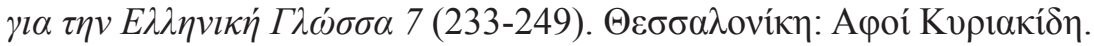

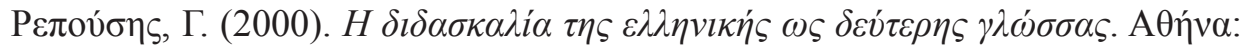

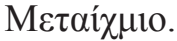

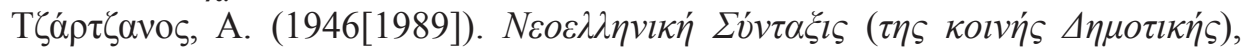

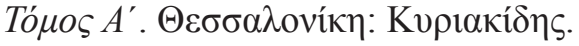

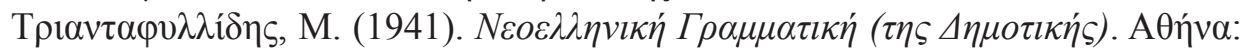

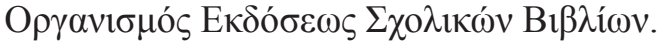

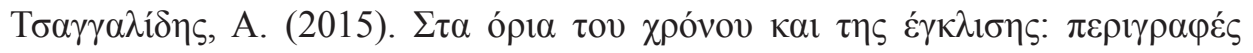

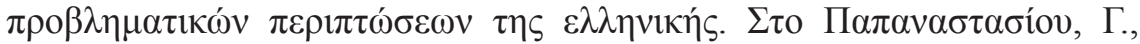

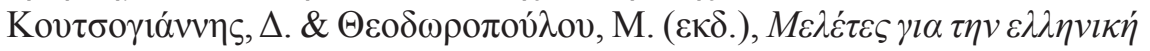

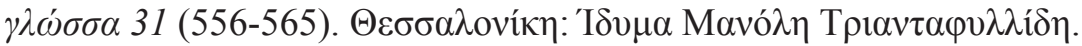

Пипер, П., Антонић, И., Ружић, В. и др. (2005): Синйакса савременоїа срииской језика: Простиа реченица. Београд: Завод за уџбенике и наставна средства и Институт за српски језик. Нови Сад: Матица српска.

Пипер, П., Клајн, И. (2017). Нормайивна ірамайика срйскої језика. Нови Сад: Матица српска. 
Станојчић, Ж., Поповић, Љ. (2000). Грамайика срӣскоїа језика. Београд: Завод за уџбенике и наставна средства.

Стевановић, М. (1981). Савремени срйскохрвайски језик I. Београд: Научна књига.

\author{
Војкан Б. Стојичић \\ Марта П. Ламбропулу \\ Анка М. Јанковић
}

\title{
ТУМАЧЕЊЕ КОНЈУНКТИВА У МОДЕРНОМ ГРЧКОМ КАО СТРАНОМ ЈЕЗИКУ: СТУДИЈА СЛУЧАЈА СА СТУДЕНТИМА ИЗ СРБИЈЕ
}

\section{Сажетак}

Конјунктив може представљати проблематично поље у усвајању модерног грчког језика као страног због тога што је његова употреба нераскидиво повезана са аспектуалношћу, која се у грчком језику исказује на синтаксичком нивоу. С обзиром на то да је аспектуалност семантичка појава у коју спада глаголски аспект, за изворне говорнике употреба перфективног или имперфективног аспекта је природна ствар, док за све оне који уче модерни грчки језик он представља велики изазов. У прилог овоме говори већи број студија, у којима је употреба конјунктива анализирана како код хеленофоних говорника, тако и код говорника других језика који уче модерни грчки као страни језик. Овај рад представља покушај да се детаљније истражи семантички аспект категорије глаголског аспекта и у утицај аспектуалности на одабир перфективног/имперфективног аспекта. У истраживању је учествовало 78 студената Катедре за неохеленске студије Филолошког факултета БУ који су попунили упитник у ком су глаголи у реченицама на српском језику преведени перфективним и имперфективним аспектом на грчком језику. Истраживање је показало да студенти неохеленистике имају добро развијен језички осећај када треба употребити перфективни или имперфективни аспект, али да ниво учења језика нема утицај на исправност одабира. Рад се ослања на претходно истраживање које су спровели Ламбропулу и Стојичић (2018), а које се односи на коришћење правилних облика конјунктива у свакодневним комуникативним ситуацијама (анализа писаног и говорог дискурса).

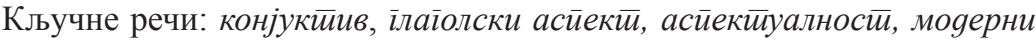
ірчки као стирани. 